\title{
Kajian Strategi Pemasaran Obyek Wisata Gunung Kawi Tampaksiring Kabupaten Gianyar Ditinjau dari Persepsi Wisatawan
}

\author{
I Made Astrama ${ }^{(1)}$ \\ I Gede Aryana Mahayasa ${ }^{(2)}$ \\ (1)(2) Fakultas Ekonomi Bisnis dan Pariwisata, Universitas Hindhu Indonesia \\ e-mail:madeastrama59@gmail.com,aryanamahayasa@unhi.ac.id
}

\begin{tabular}{|l|l|l|}
\hline Diterima: 7 Januari 2021 & Direvisi: 30 Januari 2021 & Disetujui: 5 Pebruari 2021
\end{tabular}

\begin{abstract}
The purpose of this research is to study the marketing strategy model of the Gunung Kawi Cliff Temple in Tampaksiring. The main target of tourism development must be to improve the welfare of the community, especially the people of Tampaksiring Gianyar. Respondents were 74 tourists. The research was conducted by sampling. This study uses descriptive analysis to determine inferential by evaluating the measurement model (outer model) and the structural model (structural model / inner model). The results show that the attributes of tourism objects have a positive and significant effect on the image, the promotion has a significant effect on the image, and individual characteristics have a positive and significant effect on the image, but the image itself has a positive and significant influence on the decision of tourists to visit tourist objects. Tebing Gunung Kawi Temple, Tampasiring.
\end{abstract}

Keywords: tourism object attributes, promotion, individual characteristics, image, visiting decision making

\section{Pendahuluan}

Sektor pariwisata di Indonesia saat ini dinilai efektif peranannya dalam menambah devisa negara. Hal tersebut tidak terlepas dari perkembangan kebutuhan pariwisata, tidak hanya di Indonesia, namun di seluruh dunia. Pertumbuhan kebutuhan manusia akan pariwisata menyebabkan sektor ini dinilai mempunyai prospek yang besar di masa yang akan datang. Sektor pariwisata mampu menghidupkan ekonomi masyarakat di sekitarnya, pariwisata juga diposisikan sebagai sarana penting dalam rangka memperkenalkan budaya dan keindahan alam daerah terkait. Menurut Norval dalam Spillane (1987), seorang ahli ekonomi berkebangsaan Inggris memaparkan bahwa pariwisata selain bermanfaat bagi pendidikan kebudayaan dan sosial juga mempunyai arti yang lebih penting dari segi ekonomi. Banyak negara di dunia menganggap pariwisata sebagai invisible export atas barang dan jasa pelayanan kepariwisataan yang dapat memperkuat neraca pemasukan. Pariwisata merupakan sumber pendapatan yang dapat terus diperbaharui dan 
diremajakan, dengan bentuk berupa renovasi, dan perawatan secara teratur. Oleh sebab itu pariwisata merupakan investasi yang penting pada sektor non migas bagi Indonesia. Pariwisata yang merupakan investasi ekonomi masa depan yang akan secara otomatis mempermudah perputaran barang dan jasa pelayanan di tempat wisata. Lebih jauh lagi pariwisata akan meningkatkan stabilitas ekonomi nasional, namun tentu saja keberhasilan dalam pengembangan pariwisata akan mampu dirasakan apabila faktor-faktor pendukungnya telah dipersiapkan dengan baik.

Candi Tebing Gunung Kawi, situs purbakala terletak di Br. Penaka, Desa Tampaksiring, Kec. Tampaksiring, Kab. Gianyar merupakan salah satu destinasi wisata yang menjadi tujuan utama bagi wisatawan domestik maupun asing untuk dikunjugi. Tempat ini kerap juga disebut hanya dengan nama pura Gunung Kawi, yang merupakan peninggalan purbakala berada di kawasan sawah berundak serta lembah yang asri. Objek wisata Candi Tebing Gunung Kawi di Tampaksiring menjadi tujuan wisata menarik bagi masyarakat umum. Anak-anak sekolah pada saat-saat liburan sekolah banyak yang mengagendakan study tour di Bali dan berkunjung ke pura Gunung Kawi. Selain menambah pengetahuan tentang peninggalan bersejarah mengenai situs arkeolog, juga pengunjung akan disuguhi pemandangan sawah berundak, mengenal tata cara irigasi Bali yang dikenal dengan nama subak dan pemandangan lembah sungai Pakerisan yang jermih dengan pepohonan hijau dan rimbun. Destinasi wisata sejarah dan alam di kawasan Candi Tebing Gunung Kawi ini bisa menjadi pilihan tempat wisata dan destinasi perjalanan selain pantai di Bali.

Objek wisata Candi Tebing Gunung Kawi di Tampaksiring Gianyar Bali adalah salah satu pusaka budaya yang memiliki ciri khas dan keunikan bila dibandingkan dengan tinggalan budaya lainnya. Kondisi ini sangat menarik minat para wisatawan untuk berkunjung, dan didukung dengan telah difungsikannya sebagai tempat suci, tempat persembahyangan umat Hindu. Tidak mengherankan objek wisata Candi Tebing Gunung Kawi di Tampaksiring Gianyar, merupakan daya tarik wisata yang cukup banyak menyerap pengunjung dan menjadikannya sebagai salah satu tujuan wisata unggulan di Kabupaten Gianyar, selain Gua Gajah dan Gunung Kawi Sebatu. Pusaka budaya Candi Tebing Gunung Kawi di Tampaksiring ini telah diajukan sebagai Warisan Budaya Dunia (Setiawan, 2011).

Lisma, dkk. (2017) menyatakan bahwa variabel promosi, pelayanan, dan kepuasan secara bersama-sama berpengaruh signifikan terhadap kunjungan wisatawan ke objek wisata syariah Sumatera Barat, tetapi untuk pengaruh parsial, promosi dinyatakan tidak berpengaruh secara signifikan. Menurut Kalebos (2016) kualitas pelayanan, kualitas produk wisata, serta obyek dan daya tarik wisata alam secara simultan atau serentak berpengaruh terhadap kepuasan wisatawan 
yang berkunjung ke obyek wisata di Kabupaten Kepulauan Sitaro, namun secara parsial obyek dan daya tarik wisata alam secara parsial tidak berpengaruh terhadap kepuasan wisatawan yang berkunjung ke obyek wisata di Kabupaten Kepulauan Sitaro. Variabel ini tidak berpengaruh dan memiliki hubungan negatif dengan kepuasan wisatawan. Dari beberapa hasil penelitian terdahulu diketahui bahwa banyak faktor yang mempengaruhi wisatawan dalam berkunjung ke daerah/destinasi wisata, seperti faktor promosi, atribut obyek wisata, image konsumen atau faktor kebutuhan dan gaya hidup konsumen. Informasi yang tersaji dari hasil penelitian tersebut sudah tentu menimbulkan masalah bagi para pemasar, apakah strategi pemasaran yang disusun harus mengutamakan promosi, mengedepankan atribut obyek wisata, atau berusaha keras untuk menciptakan image konsumen yang positif. Demikian halnya yang dialami oleh pengelola obyek ekowisata Candi Tebing Gunung Kawi di Tampaksiring. Mereka mengalami masalah dalam merumuskan strategi pemasaran yang tepat, untuk meningkatkan jumlah kunjungan wisata ke obyek ekowisata tersebut. Kondisi faktual laju relatif jumlah kunjungan wisatawan ke obyek Candi Tebing Gunung Kawi di Tampaksiring terhadap jumlah kunjungan wisatawan ke Bali mengalami trend penurunan, walaupun obyek ekowisata Candi Tebing Gunung Kawi di Tampaksiring sesungguhnya merupakan obyek wisata yang terkemuka di Bali.

Trend yang menurun dari laju relatif jumlah kunjungan wisatawan ke obyek ekowisata Candi Tebing Gunung Kawi di Tampaksiring mengindikasikan bahwa ada permasalahan yang menyelimuti obyek ekowisata Candi Tebing Gunung Kawi di Tampaksiring. Permasalahan yang terjadi perlu segera diidentifikasi apakah terkait dengan faktor promosi, atribut atraksi wisata, karakteristik pengunjung, image konsumen, daya tarik obyak wisata, atau jalinan dari beberapa faktor tersebut. Untuk menjawab sejumlah permasalahan tersebut, maka sangat mendesak dilakukan penelitian tentang strategi pemasaran untuk meningkatkan jumlah kunjungan wisatawan ke obyek wisata Candi Tebing Gunung Kawi di Tampaksiring. Berdasarkan gambaran yang telah diuraikan pada latar belakang masalah dan dilandasi oleh pemikiran teoritis serta empirik, maka dapat diajukan pokok permasalahan dalam penelitian ini adalah bagaimanakah model strategi pemasaran Candi Tebing Gunung Kawi di Tampaksiring.

Candi Tebing Gunung Kawi Tampaksiring yang letaknya berdampingan kawasan wisata Ubud dan Tegallalang merupakan kawasan wisata dengan potensi alam persawahan dengan latar belakang pepohonan yang rindang, dan dipadu dengan sistem pertanian tradisional masyarakat Bali (subak), sawah terasering, bentang alam yang masih terjaga serta seni budaya yang beraneka ragam, merupakan suatu nuansa alam yang sangat mempesona dan sangat penting dijaga kelestariannya. Konsep penelitian ini yakni mengkaji tentang model strategi pemasaran Candi 
Tebing Gunung Kawi di Tampaksiring yang sasaran utama pengembangan kepariwisataan haruslah meningkatkan kesejahteraan masyarakat, khususnya masyarakat Tampaksiring Gianyar.

\section{Telaah Literatur dan Kajian Pustaka}

\section{Pariwisata}

Pariwisata bukanlah istilah yang asing di telinga. Pendit (2003), menjelaskan bahwa istilah pariwisata pertama kali diperkenalkan oleh dua budayawan pada sekitar tahun 1960, yaitu Moh. Yamin dan Prijono. Kedua budayawan ini memberikan masukan kepada pemerintah saat itu untuk mengganti istilah tour agar sesuai dengan bahasa khas Nusantara. Istilah pariwisata sendiri berasal dari bahasa Sansekerta yaitu sebagai berikut : Pari = penuh, lengkap, keliling; Wis $($ man $)=$ rumah, properti, kampung, komunitas; Ata = pergi, terus menerus, mengembara. Sehingga bila diartikan secara keseluruhan, pariwisata adalah pergi secara lengkap, meninggalkan rumah (kampung) untuk berkeliling secara terus menerus. Pariwisata menurut Spillane (1987:20) adalah perjalanan dari satu tempat ke tempat lain, bersifat sementara, dilakukan perorangan maupun kelompok, sebagai usaha mencari keseimbangan/keserasian dan kebahagiaan dengan lingkungan hidup dalam dimensi social, budaya, alam dan ilmu. Sedangkan Pendit (2003:20), mendefinisikan pariwisata sebagai suatu proses kepergian sementara dari seseorang atau lebih menuju tempat lain di luar tempat tinggalnya. Dorongan kepergiannya adalah karena berbagai kepentingan, baik karena kepentingan ekonomi, sosial, kebudayaan, politik, agama, kesehatan maupun kepentingan lain seperti karena sekedar ingin tahu, menambah pengalaman ataupun untuk belajar. Wahab dalam Yoeti (2008: 111), menjelaskan pariwisata sebagai suatu aktivitas manusia yang dilakukan secara sadar yang mendapat pelayanan secara bergantian diantara orang-orang dalam suatu negara itu sendiri atau diluar negeri, meliputi pendiaman orang-orang dari daerah lain untuk sementara waktu mencari kepuasan yang beraneka ragam dan berbeda dengan apa yang dialaminya, dimana ia memperoleh pekerjaan tetap. Dalam Undang-Undang Nomor 90 Tahun 1990 tentang Keparwisataan dijelaskan bahwa wisata adalah kegiatan perjalanan atau sebagian dari kegiatan tersebut yang dilakukan secara sukarela serta bersifat sementara untuk menikmati objek dan daya tarik wisata. Sedangkan pariwisata adalah segala sesuatu yang berhubungan dengan wisata, termasuk pengusahaan objek dan daya tarik wisata serta usaha-usaha yang terkait di bidang tersebut. Orang yang berpariwisata disebut wisatawan. Suwantoro (2004), mengartikan wisatawan adalah seseorang atau sekelompok orang yang melakukan suatu perjalanan wisata dengan waktu tinggalnya sekurang kurangnya 24 jam di daerah atau negara lain, jika waktu wisata kurang dari 24 jam maka dapat disebut dengan pelancong. Selanjutnya, seseorang dapat dikatakan melakukan perjalanan wisata apabila: bersifat sementara, sukarela, dan tidak bertujuan untuk bekerja. 


\section{Jenis Pariwisata}

Suwantoro (2004), menggolongkan pariwisata menjadi beberapa jenis, yaitu dari segi: 1) jumlahnya: a) individual tour, yaitu suatu perjalanan wisata yang dilakukan oleh satu orang atau sepasang suami istri; b) family group tour, yaitu suatu perjalanan wisata yang dilakukan oleh serombongan keluarga yang masih mempunyai hubungan kekerabatan satu sama lain; c) group tour, yaitu suatu perjalanan wisata yang dilakukan bersama sama minimal 10 orang, dengan dipimpin oleh seorang yang bertanggung jawab atas keselamatan dan kebutuhan seluruh anggotanya. 2) Kepengaturannya: a) pre arranged tour, b) package tour, c) coach tour, d) special arranged tour, e) optional tour. 3) Maksud dan tujuan: a) holiday tour, b) familiarization tour, c) educational tour, d) pileimage tour, e) special 10 mission tour, f) special programe tour, g) hunting tour. 4) Penyelenggaraannya: ekskursi, safari tour, cruize tour, youth tour, wreck diving. Spillane (1987), membedakan jenis-jenis menjadi pariwisata untuk: 1) menikmati perjalanan (pleasure tourism), 2) rekreasi (recreation tourism), 3) kebudayaan (cultural tourism), 4) olahraga (sports tourism), 5) urusan usaha dagang (business tourism), 6) berkonvensi (convention tourism).

Pariwisata untuk menikmati perjalanan (pleasure tourism), dilakukan oleh orang-orang yang meninggalkan tempat tinggalnya untuk berlibur, untuk mencari udara segar yang baru, untuk memenuhi kehendak ingin tahunya, untuk mengendorkan ketegangan sarafnya, untuk melihat sesuatu yang baru, untuk menikmati keindahan alam, atau bahkan untuk mendapatkan ketenangan dan kedamaian di daerah luar kota. Pariwisata untuk rekreasi (recreation tourism) dilakukan oleh orang-orang yang menghendaki pemanfaatan hari-hari liburnya untuk beristirahat, untuk memulihkan kembali kesegaran jasmani dan rohaninya, yang ingin menyegarkan keletihan dan kelelahannya. Pariwisata untuk kebudayaan (cultural tourism) dilakukan karena adanya keinginan untuk mempelajari adat istiadat, kelembagaan, dan cara hidup rakyat daerah lain, selain itu untuk mengunjungi monumen bersejarah, peninggalan peradaban masa lalu, pusat-pusat kesenian, pusatpusat keagamaan, atau untuk ikut serta dalam festival-festival seni musik, teater, tarian rakyat, dan lain-lain. Pariwisata untuk olahraga (sports tourism) dapat dibagi dalam dua kategori: big sports event, pariwisata yang dilakukan karena adanya peristiwa-peristiwa olahraga besar seperti Olympiade Games, World Cup, dan sporting tourism of the practitioner, yaitu pariwisata olahraga bagi mereka yang ingin berlatih dan mempraktekan sendiri, seperti pendakian gunung, olahraga naik kuda, dan lain-lain. Pariwisata untuk urusan usaha dagang (business tourism) adalah bentuk professional travel atau perjalanan karena ada kaitannya dengan pekerjaan atau jabatan yang tidak memberikan kepada pelakunya baik pilihan daerah tujuan maupun pilihan waktu perjalanan. 
Pariwisata untuk berkonvensi (convention tourism) sering dihadiri oleh ratusan dan bahkan ribuan peserta yang biasanya tinggal beberapa hari di kota atau negara penyelenggara.

\section{Atribut Produk}

Tjiptono (1997) menyatakan bahwa atribut produk adalah unsure-unsur yang dipandang penting oleh konsumen dan dijadikan dasar pengambilan keputusan pembelian. Atribut produk meliputi merek, kemasan, jaminan, pelayanan, dan sebagainya. Ada beberapa macam klasifikasi atribut produk. Gartner (1993) dalam penelitiannya terhadap wisatawan Korea menyatakan bahwa wisatawan berkunjung ke Korea karena termotivasi oleh tangibles attribute (shopping) dan intangibles attribute (local culture). Law (1995) menyatakan bahwa ada dua faktor yang berkontribusi terhadap ketertarikan daerah wisata, yaitu faktor primer dan sekunder. Faktor primer berisi iklim daerah wisata, lingkungan, tradisi budaya, arsitek tradisional dan sumber alami. Faktor sekunder berisi barang berwujud dan tidak berwujud yang langsung dikembangkan oleh wisatawan seperti hotel, catering, aktivitas dan atraksi penunjang.

\section{Promosi}

Promosi adalah sejenis komunikasi yang memberikan penjelasan yang meyakinkan kepada calon konsumen tentang barang dan jasa (Simamora, 2004). Selanjutnya Payne (1993) menyatakan bahwa promosi merupakan alat yang dapat digunakan oleh organisasi jasa untuk berkomunikasi dengan pasar sasarannya. Komunikasi adalah proses membagi ide, informasi atau perasaan audiens, tujuan promosi adalah menginformasikan, membujuk dan mengingatkan keberadaan suatu produk kepada konsumen. Stanton (1990) menyatakan ada empat faktor yang mempengaruhi promosi, yaitu banyaknya uang yang tersedia untuk promosi, keadaan pasar, keadaan produk, apakah untuk konsumen akhir atau sebagai bahan industri, dan tingkat pencapaian siklus kehidupan produk. Selanjutnya Simamora (2004) mengemukakan bahwa faktor yang mempengaruhi promosi adalah (1) pemasar, apakah menggunakan push atau pull strategy, (2) target pasar, yakni siapa calon konsumennya dan dimana lokasinya, (3) produk, yaitu posisi produk dalam siklus kehidupan produk, dan (4) situasi lingkungan seperti persaingan, ekonomi, dan politik.

\section{Karakteristik Lingkungan}

Menurut Kotler (2003), perilaku konsumen dalam membeli barang atau jasa dipengaruhi oleh stimuli pemasaran dan karakteristik pembeli. Selanjutnya dikemukakan bahwa karakteristik pembeli meliputi faktor budaya, sosial, pribadi, dan psikologis. Faktor budaya memiliki pengaruh yang meluas dan mendalam terhadap perilaku pembelian, seperti tata nilai, perilaku keluarga, preferensi, agama, kebangsaan, rasa dan daerah geografis. Faktor sosial yang mempengaruhi perilaku pembelian konsumen yaitu kelompok acuan, keluarga, peran dan status social. 
Kelompok acuan seseorang terdiri dari semua kelompok yang mempunyai pengaruh langsung atau tak langsung terhadap pendirian atau perilaku seseorang. Kelompok ini berada pada suatu tempat dimana orang tersebut berinteraksi dan terdiri dari kelompok primer dan sekunder. Kelompok primer cenderung bersifat informal seperti keluarga, teman, tetangga, dan rekan kerja. Sedangkan kelompok sekunder lebih bersifat formal seperti kelompok keagamaan, profesi, dan asosiasi perdagangan. Anggota keluarga merupakan kelompok primer yang paling berpengaruh. Pengaruh yang lebih langsung terhadap perilaku pembelian sehari-hari adalah keluarga prokreasi seseorang, yaitu pasangan dan anak-anaknya. Keluarga, yaitu organisasi pembelian konsumen yang paling penting dalam masyarakat.

Para pemasar tertarik dengan peran dan pengaruh relatif dari seorang suami, istri, dan anakanak dalam pembelian berbagai produk barang maupun jasa. Peran dan pengaruh ini akan sangat bervariasi pada negara-negara dan kelas sosial yang berbeda. Faktor pribadi yang mempengaruhi perilaku pembelian seseorang adalah usia, siklus hidup, pekerjaan, keadaan ekonomis dan konsep pribadi pembeli. Menurut Kotler (2003) siklus hidup keluarga meliputi 9 tahap yaitu, tahap bujangan, pasangan muda, keluarga penuh I (anak terkecil kurang dari 6 bulan), keluarga penuh II (anak terkecil berusia di atas 6 tahun), keluarga penuh III (pasangan suami istri berusia lebih tua dengan anak-anak yang mandiri), keluarga kosing I (pasangan suami istri berusia lebih tua, tidak ada anak yang tinggal bersama mereka dan sudah pension), hidup sendirian bekerja dan hidup sendirian pension.

Pilihan pembelian seseorang juga dipengaruhi oleh faktor psikologis, yang meliputi motivasi, persepsi, pengetahuan, dan kepercayaan. Ahli psikologi telah mengembangkan teori motivasi manusia, diantaranya adalah Sigmund Freud, Frederick Herzberg dan Abraham Maslow (Kotler, 2003). Teori Freud mengasumsikan bahwa kekuatan psikologis riil yang membentuk prilaku seseorang, sebagian besar bersifat tidak sadar. Freud melihat seseorang menahan banyak keinginan dalam proses pertumbuhan dan menerima aturan-aturan social. Keinginan-keinginan ini tidak pernah dapat dihapuskan atau dikendalikan dengan sempurna. Keinginan ini muncul dalam mimpi dan dalam perilaku karena gangguan emosi.

Maslow menjelaskan mengapa seseorang terdorong oleh kebutuhan-kebutuhan tertentu pada waktu tertentu. Jawabnya adalah bahwa kebutuhan manusia tersusun dalam suatu hierarki dari yang paling mendesak hingga sampai yang paling tidak mendesak. Sesuai dengan urutan pentingnya, kebutuhan manusia tersebut adalah kebutuhan fisiologis, kebutuhan keamanan, kebutuhan social, kebutuhan penghargaan dan kebutuhan aktualisasi diri. Teori Maslow dapat 
membantu para pemasar untuk memahami bagaimana suatu produk dapat sesuai dengan kebutuhan dan selera konsumen.

\section{Karakteristik Obyek Ekowisata di Indonesia}

Bisnis kepariwisataan adalah bisnis jasa yang bertujuan memberikan keuntungan baik bagi wisatawan, warga setempat, maupun kepada pemerintah daerah. Pariwisata dapat memberikan kehidupan yang standar kepada warga setempat melalui keuntungan ekonomi yang diperoleh dari tempat tujuan wisata (obyek wisata). Bagi pemerintah daerah, pengembangan bisnis kepariwisataan dapat memberikan kontribusi yang berarti bagi pendapatan asli daerah. Bisnis kepariwisataan tercermin dalam pasal 1 angka 5 UU No. 9 tahun 1990 bahwa usaha pariwisata diartikan sebagai kegiatan yang bertujuan menyelenggarakan jasa pariwisata atau menyediakan atau mengusahakan obyek dan daya tarik wisata, usaha sarana pariwisata dan usaha lain yang terkait dengan bidang tersebut. Berdasarkan batasan tersebut, maka usaha pariwisata dapat dibedakan dalam tiga kelompok, yaitu usaha jasa pariwisata, usaha obyek wisata, dan usaha sarana pariwisata.

Fokus pembahasan pada penelitian ini adalah usaha obyek wisata. Menurut Marpaung (2002) atraksi obyek wisata alam dibedakan dalam pemandangan, pantai, taman, gunung, flora/fauna dan pulau terpencil. Sedangkan Fandeli (1995) mengemukakan bahwa atraksi wisata alam di Indonesia dibedakan atas pegunungan, dataran tinggi, sungai, air terjun, danau, pemandangan, laut, pantai, pulau, mata air panas, binatang, tumbuhan, lembah, kawah, goa, tanjung, dan cagar alam. Menurut Fandeli (1995), ada dua faktor penting yang mempengaruhi wisatawan datang ke tempat wisata, yaitu faktor pendorong dan faktor penarik. Faktor yang mendorong seseorang pergi berwisata adalah ingin terlepas dari kehidupan yang rutin setiap hari, lingkungan yang tercemar, kecepatan lalu lintas dan hiruk pikuk kesibukan di kota. Sedangkan faktor yang menarik kedatangan wisatawan ke tempat wisata adalah berhubungan dengan atraksi. Atraksi wisata dapat berupa kemasyuran akan obyek wisata, tempat-tempat yang banyak diperbincangkan orang dan sedang menjadi berita.

\section{Image Konsumen}

Sutisna (2003) mendefinisikan image sebagai gambaran mental atau konsep tentang sesuatu, sedangkan Bennet (1995) mengemukakan bahwa image adalah persepsi konsumen terhadap produk, institusi, merek, perusahaan atau orang yang sesuai atau tidak sesuai dengan kenyataan. Crompton (1979) dalam Ahmed (1996) mengemukakan bahwa image adalah sejumlah kepercayaan, ide, kesan dan harapan yang dimiliki wisatawan terhadap tujuan wisata. Kotler (2003) mendefinisikan image sebagai sejumlah keyakinan, gambaran, dan kesan-kesan yang dipunyai 
seseorang terhadap suatu obyek. Gronroos (1990) menyatakan bahwa image adalah realitas. Oleh karena itu program pengembangan dan perbaikan image harus didasarkan pada realitas. Simamora (2002) menyatakan bahwa ada dua pendekatan untuk mengukur image konsumen, yaitu (1) pendekatan tidak terstruktur, yaitu merefleksikan image di benak konsumen menurut mereka sendiri, dan (2) pendekatan terstruktur, yaitu peneliti menjelaskan dimensi yang jelas, kemudian responden merespon dimensi yang ditanyakan. Gronroos (1990) menjelaskan ada empat peran image bagi suatu organisasi. Pertama, image menceritakan harapan bersama dengan kampanye pemasaran eksternal, seperti periklanan, penjualan tatap muka dan komunikasi dari mulut ke mulut. Kedua, image sebagai penyaring yang mempengaruhi persepsi pada kegiatan perusahaan, ketiga image adalah fungsi dari pengalaman dan harapan konsumen, dan Keempat, image berpengaruh penting pada manajemen yang mempunyai dampak internal. Image positif secara internal akan menceritakan nilai-nilai yang jelas dan menguatkan sikap positif terhadap organisasi.

Terkait dengan pentingnya image bagi wisatawan, maka Andreu et al. (2000) menyatakan bahwa image merupakan kepercayaan dan persepsi orang terhadap tujuan wisata yang dipengaruhi oleh pertumbuhan area wisata atau sumber fisik. Image bersifat subyektif sehingga menyebabkan image yang diterima wisatawan tidak sama dengan kenyataan yang ada. Menurut Moutinho (1987), ada tiga komponen yang mempengaruhi bentuk image, yaitu tingkat pengetahuan terhadap tujuan wisata, kepercayaan dan sikap terhadap produk, dan harapan yang diinginkan dan produk.

\section{Pengambilan Keputusan Pembelian}

Menurut Hawkins, et al (1988), perilaku konsumen merupakan suatu proses pengambilan keputusan yang mensyaratkan aktivitas individu untuk mengevaluasi, memperoleh dan menggunakan barang dan jasa. Lebih lanjut Hawkins, et al (1988) mengemukakan bahwa perilaku konsumen adalah studi terhadap individu, kelompok atau organisasi dan proses yang mereka gunakan untuk memilih, mengamankan, menggunakan dan menentukan produk, service, pengalaman atau ide untuk memuaskan kebutuhan. Faktor-faktor yang mempengaruhi perilaku pembelian konsumen adalah faktor internal dan faktor eksternal. Faktor internal meliputi persepsi, motivasi, sikap, emosi, ingatan dan personality, sedangkan faktor eksternal meliputi kebudayaan, kelas social, keluarga, referensi kelompok, aktivitas pemasaran, pelayanan, fasilitas dan promosi.

Menurut Engel et al (1995), perilaku konsumen adalah tindakan yang langsung terlibat untuk mendapatkan, mengkonsumsi dan menghabiskan produk dan jasa, termasuk proses yang mendahului dan mengikuti tindakan tersebut. proses pengembilan keputusan pembelian dipengaruhi oleh faktor lingkungan dan perbedaan individu. Tahapan yang dilakukan konsumen dalam mengambil keputusan pembelian dimulai dari kesadaran adanya kebutuhan, kemudian 
pencarian informasi, evaluasi alternative menjelang pembelian, pembelian, konsumsi, hasil yang berupa kepuasan ataupun ketidakpuasan.

\section{Metode Penelitian}

Variabel-variabel yang digunakan dalam penelitian ini terdiri dari variabel atribut obyek wisata, promosi, karakteristik individu, image, dan keputusan berkunjung ke Objek Wisata Candi Tebing Gunung Kawi Tampaksiring. Populasi penelitian adalah wisatawan, baik wisatawan asing maupun wisatawan domestik yang telah bekunjung ke Objek Wisata Candi Tebing Gunung Kawi Tampaksiring. Total responden diperoleh 74 orang responden yang merupakan wisatawan yang berkunjung ke Objek Wisata Candi Tebing Gunung Kawi Tampaksiring. Metode penentuan sampel atau responden adalah probability sampling dengan pendekatan accidental sampling.

Analisis data penelitian menggunakan metode analisis partial least square (PLS). Dalam analisis partial least square (PLS) terdiri dari evaluasi goodness-of-fit outer model, evaluasi goodness-of-fit inner model, dan uji signifikansi hipotesis. Model pengukuran atau outer model dievaluasi dengan convergent dan discriminant validity dari indikatornya dan composite realibility untuk blok indikator. Pengukuran discriminant validity dilakukan dengan cara membandingkan nilai square root average variance extracted (akar AVE) setiap konstruk dengan korelasi antara konstruk tersebut terhadap konstruk lainnya dalam model.

Evaluasi goodness-of-fit dari inner model dievaluasi dengan menggunakan R-square untuk variabel laten dependen dengan interprestasi yang sama dengan regresi. Sedangkan untuk mengukur model konstruk digunakan Q-square predictive relevance. Q-square dapat mengukur seberapa baik nilai observasi dihasilkan oleh model dan juga estimasi parameternya.

\section{Hasil Penelitian dan Pembahasan}

Karakteristik responden dalam penelitian ini, ditunjukkan berupa pengelompokkan responden menurut jenis kelamin, kelompok umur, dan tingkat pendidikan karyawan yang berkunjung ke Obyek Wisata Candi Tebing Gunung Kawi Tampaksiring. Ditinjau dari jenis kelaminnya, mayoritas responden berjenis kelamin perempuan yaitu sejumlah 47 orang $(63,51 \%)$. Selebihnya adalah laki-laki, yaitu sebanyak 27 orang atau 36,49 \%. Ditinjau dari kelompok usia, maka mayoritas responden berada pada kisaran kelompok umur antara 27-44 dan 45-64 tahun, yaitu masing-masing sebanyak 37 orang atau 50\%, sementara itu tidak ada responden yang berumur kurang dari 18 tahun dan lebih dari 65 tahun. Dari tingkat pendidikannya mayoritas responden berpendidikan S1, yaitu sebanyak 43 orang atau 58,11\%. Selebihnya adalah berpendidikan SMA, Diploma, dan S2. 
Hasil evaluasi outer model menghasilkan bahwa semua indikator memiliki loading factor lebih besar dari 0,60. Dengan demikian dapat dinyatakan bahwa semua indikator adalah valid dan reliabel untuk merefleksikan masing-masing variabelnya. Koefisin square root average variance extracted (akar AVE) untuk setiap variabel adalah lebih besar dari 0,5. Square root average variance extracted (akar AVE) setiap konstruk paling besar dibandingkan dengan korelasi antara konstruk tersebut terhadap konstruk lainnya dalam model. Dengan demikian dapat dinyatakan bahwa discriminant validity untuk setiap variabel terpenuhi. Semua nilai composite reliability > 0,7. Ini berarti syarat keempat uji composite reliability telah terpenuhi. Nilai Cronbach's Alpha > 0,6. Ini berarti syarat kelima uji composite reliability telah terpenuhi. Hal ini berarti syarat reliabilitas terpenuhi.

Tabel 1: $R$-square dan $Q$-square

\begin{tabular}{lc}
\multicolumn{1}{c}{ Variabel } & R-square \\
\hline Atribut Obyek Wisata (X1) & \\
Promosi (X2) & 0,923 \\
Karakteristik individu (X3) & 0,592 \\
Image(Y1) & \\
Keputusan Berkunjung (Y2) & \\
Kalkulasi: & \\
Q2 $=1-[(1-\mathrm{R} 12)(1-\mathrm{R} 22)]$ & \\
$\mathrm{Q} 2=1-[(1-0,851929)(1-0,350464)]=0,96177$ & \\
\hline
\end{tabular}

Pada Tabel 1 terlihat koefisien $\mathrm{R}^{2}$ untuk variabel image adalah sebesar 0,923. Artinya 92,3\% perubahan image dipengaruhi oleh perubahan atribut, promosi dan karakteristik individu. Sedangkan koefisien $\mathrm{R}^{2}$ untuk variable keputusan berkunjung adalah sebesar 0,592. Artinya 59,2\% perubahan keputusan berkunjung dipengaruhi oleh perubahan atribut, promosi karakteristik individu, dan image. Nilai Q-square $>0$ berarti menunjukan bahwa model memiliki predictive relevance.

Uji signifikansi hipotesis untuk mengetahui hubungan kausalitas antara dua variabel yang disimpulkan memiliki pengaruh yang nyata atau signifikan apabila nilai dari t-statistik>1,96 (untuk penelitian satu arah/one tailed).

\section{Tabel 2: Uji Signifikansi Hipotesis}

\begin{tabular}{lccc}
\hline Koefisien Path Antar Variabel & Koefisien Jalur & $\boldsymbol{t}$ Statistics & Keterangan \\
\hline$\left(\mathrm{X}_{1}\right) \rightarrow(\mathrm{Y} 1)$ & 0,547 & 6,848 & Signifikan \\
$\left(\mathrm{X}_{2}\right) \rightarrow(\mathrm{Y} 1)$ & 0,059 & 0,399 & Tidak Signifikan \\
$\left(\mathrm{X}_{3}\right) \rightarrow(\mathrm{Y} 1)$ & 0,446 & 2,979 & Signifikan \\
$(\mathrm{Y} 1) \rightarrow(\mathrm{Y} 2)$ & 0,806 & 18,423 & Signifikan \\
\hline
\end{tabular}


1. Pengaruh atribut obyek wisata Candi Tebing Gunung Kawi Tampaksiring terhadap image wisatawan

Tabel 2 menunjukkan bahwa nilai original sample estimate atribut obek wisata dengan image adalah sebesar 0,547 dengan signifikansi dibawah 5\% yang ditunjukkan dengan nilai statistik 6,848 lebih besar dari dari nilai t-tabel sebesar 1,96 dan p value $=0,000<0,05$. Nilai original sample estimate positif mengindikasikan bahwa atribut obyek wisata berpengaruh positif signifikan terhadap image wisatawan. Dengan demikian dapat dinyatakan terdapat pengaruh positip yang signifikan atribut obyek wisata Candi Tebing Gunung Kawi Tampaksiring terhadap image wisatawan.

2. Pengaruh promosi terhadap image wisatawan

Pada Tabel 2 terlihat bahwa nilai original sample estimate promosi dengan image adalah sebesar 0,059 dengan signifikansi dibawah 5\% yang ditunjukkan dengan nilai statistik 0,399 lebih kecil dari nilai t-tabel sebesar 1,96 dan p value $=0,690>0,05$. Nilai original sample estimate positif mengindikasikan bahwa promosi tidak berpengaruh signifikan terhadap image wisatawan. Artinya hipotesis yang berbunyi promosi berpengaruh positif dan signifikan terhadap image wisatawan yang berkunjung ke obyek wisata Candi Tebing Gunung Kawi Tampaksiring adalah tidak terbukti kebenarannya.

3. Pengaruh karakteristik individu terhadap image wisatawan

Pada Tabel 2 terlihat bahwa nilai original sample estimate karakteristik individu dengan image wisatawan adalah sebesar 0,446 dengan signifikansi dibawah 5\% yang ditunjukkan dengan nilai statistik 2,979 lebih besar dari dari nilai t-tabel sebesar 1,96 dan p value $=0,000<0,05$. Nilai original sample estimate positif mengindikasikan bahwa karakteristik individu berpengaruh positif dan signifikan terhadap image wisatawan. Dengan demikian dapat dinyatakan terdapat pengaruh positip yang signifikan karakteristik individu terhadap image wisatawan. Artinya hipotesis 3 yang berbunyi karakteristik individu berpengaruh positif dan signifikan terhadap image wisatawan yang berkunjung ke obyek wisata Candi Tebing Gunung Kawi Tampaksiring adalah teruji kebenarannya.

4. Pengaruh image wisatawan terhadap keputusan berkunjung

Pada Tabel 2 terlihat bahwa nilai original sample estimate image wisatawan dengan keputusan berkunjung adalah sebesar 0,806 dengan signifikansi dibawah 5\% yang ditunjukkan dengan nilai statistik 18,423 lebih besar dari nilai t-tabel sebesar 1,96 dan p value $=0,000<0,05$. Nilai original sample estimate positif mengindikasikan bahwa pengaruh image wisatawan terhadap keputusan berkunjung adalah signifikan. Dengan demikian dapat dinyatakan terdapat pengaruh 
positip dan signifikan image wisatawan terhadap keputusan berkunjung. Artinya hipotesis 4 yang berbunyi image wisatawan berpengaruh positif dan signifikan terhadap keputusan berkunjung ke obyek wisata Candi Tebing Gunung Kawi Tampaksiring adalah teruji kebenarannya.

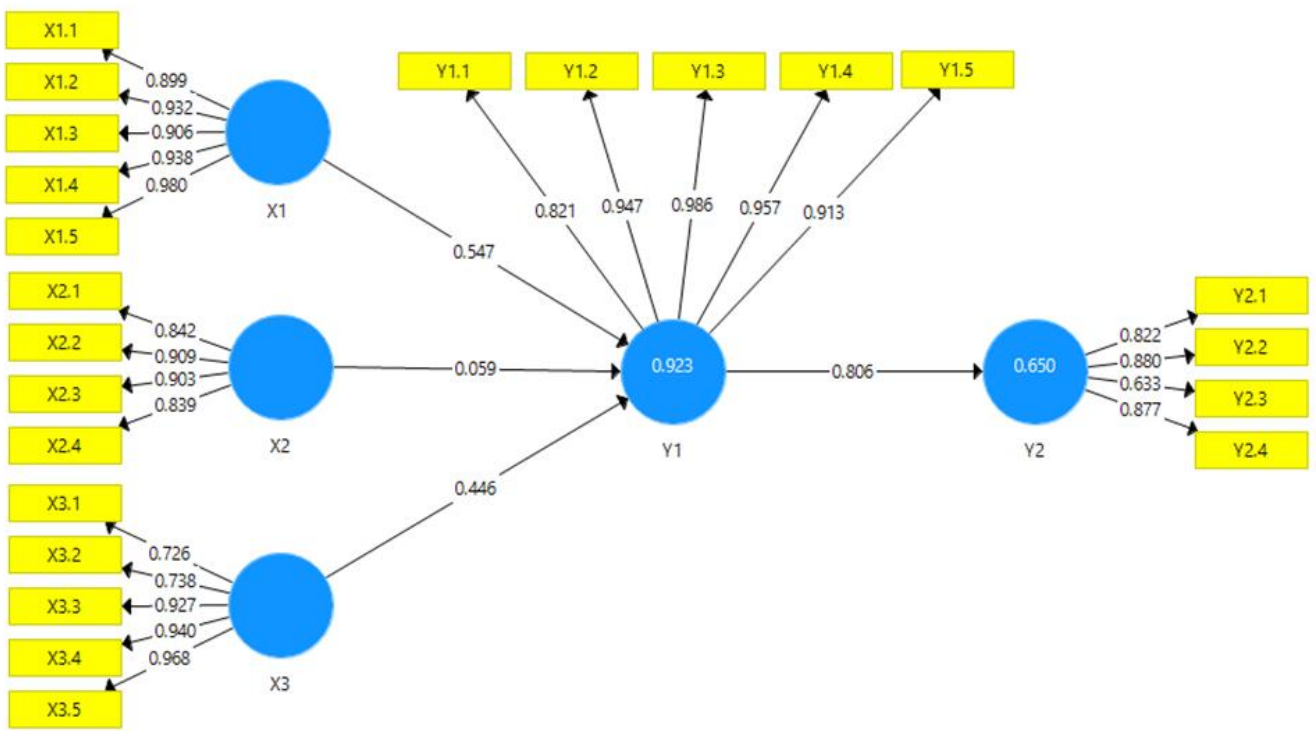

Gambar 1. Hasil Analisis Partial Least Square (PLS)

Sesuai dengan hasil analisis partial least square (PLS) pada gambar 1, pada bagian ini akan dibahas satu persatu mengenai pengaruh atribut obyek wisata terhadap image wisatawan, pengaruh promosi terhadap image wisatawan, pengaruh karakteristik individu terhadap image wisatawan, dan pengaruh image wisatawan terhadap keputusan berkunjung.

\section{Atribut Candi Tebing Gunung Kawi}

Ditinjau dari atribut obyek wisata Candi Tebing Gunung Kawi yang terdiri dari: atraksi, kemudahan terjangkau, harga, akomodasi, produk kenangan, diperoleh hasil bahwa tiga indikator yang paling kuat mempengaruhi atribut Candi Tebing Gunung Kawi adalah harga kemudian disusul akomodasi dan atraksi. Dua indikator yang paling lemah mempengaruhi atribut Candi Tebing Gunung Kawi adalah kemudahan dijangkau dan produk kenangan. Hasil ini mengindikasikan bahwa indikator harga yang terdiri dari harga tiket masuk ke obyek Candi Tebing Gunung Kawi, termasuk harga makanan/minuman di restoran serta fasilitas wisata lainnya termasuk toilet, tidak terlalu mahal dan terjangkau oleh para wisatawan yang berkunjung kesana. Indikator paling kuat berikutnya adalah akomodasi, dimana obyek Candi Tebing Gunung Kawi memiliki fasiltas penginapan yang sesuai dengan kebutuhan wisatawan yang berkunjung kesana. Atribut atraksi Candi Tebing Gunung Kawi dengan pemandangan alam yang indah dengan view hamparan sawah dan tegalan sangat menarik bagi wisatawan domestik maupun mancanegara yang 
berkunjung kesana. Ditambah lagi dengan atraksi kesenian dan budaya tradisional masyarakat Tampaksiring sangat menarik bagi wisatawan yang berkunjung ke obyek wisata ini. Atraksi Candi Tebing Gunung menarik dengan adanya aliran sungai Pakerisan yang menjadi salah satu warisan budaya dunia yang mengaliri sawah kawasan Subak Pulagan.

Produk kenangan merupakan indikator yang kurang berpengaruh terhadap atribut Candi Tebing Gunung Kawi. Hasil ini mengindikasikan bahwa diperlukan upaya yang lebih maksimal dari pengelola obyek Candi Tebing Gunung Kawi dengan memotivasi para pedagang souvenir agar dapat memberikan pelayanan yang lebih memuaskan kepada para wisatawan yang berkunjung kesana, jangan sampai ada kesan memaksa para wisatawan untuk membeli produk/jasa mereka.

\section{Promosi Obyek Candi Tebing Gunung Kawi}

Selanjutnya dapat dijelaskan mengenai promosi obyek Candi Tebing Gunung Kawi adalah melalui publikasi, word of mouth dan e-commerce. Diperoleh hasil bahwa dua indikator yang paling kuat mempengaruhi promosi obyek Candi Tebing Gunung publikasi dan word of mouth. Indikator yang paling lemah mempengaruhi promosi obyek Candi Tebing Gunung Kawi adalah $e$ commerce. Hasil ini mengindikasikan bahwa promosi obyek wisata Candi Tebing Gunung Kawi sudah cukup efektif dilakukan dengan publikasi. Selain itu promosi word of mouth juga cukup efektif dilakukan untuk promosi obyek Candi Tebing Gunung Kawi. Ini berarti para wisatawan yang berkunjung ke obyek wisata Candi Tebing Gunung Kawi telah berperan aktif turut mempromosikan obyek Candi Tebing Gunung Kawiantara lain melalui telepon seluler, video, jaringan sosial seperti lingkungan keluarga, teman, serta online dengan situs web, blog, pesan. Sebaliknya e-commerce merupakan indikator yang paling lemah mempengaruhi promosi, dengan demikian promosi obyek Candi Tebing Gunung Kawi masih perlu diperluas dengan jaringan website yaitu melalui iklan on-line, situs retail maupun jasa mal on-line sehingga dapat menjangkau jaringan internasional

\section{Karakteristik Individu}

Karakteristik individu wisatawan yang terdiri dari motivasi, pengalaman, gaya hidup, sosial dan kondisi ekonomi juga merupakan faktor yang menentukan kunjungan wisatawan ke obyek Candi Tebing Gunung Kawi. Indikator yang paling kuat berpengaruh terhadap karakteristik individu wisatawan adalah pengalaman, kemudian disusul oleh kondisis ekonomi, gaya hidup dan motivasi, sedangkan faktor yang paling kecil pengaruhnya adalah sosial.

Pengalaman wisatawan merupakan faktor yang paling kuat pengarunya terhadap karakteristik Individu wisatawan, berarti faktor pengalaman sendiri/keluarga/tetangga/rekan kerja serta jaringan sosial lainnya yang merasa puas setelah berkunjung ke obyek ekowista Kintamani, 
adalah merupakan faktor yang perlu mendapat perhatian dari Pemerintah Gianyar dan desa Tampaksiring, sehingga kepuasan wisatawan yang berkunjung ke obyek Candi Tebing Gunung Kawi ini perlu selalu diperhatikan, baik terhadap kelestarian alam, pemandangan yang indah dengan view sungai dan persawahan, atraksi budaya yang menarik serta lingkungan yang sejuk dan nyaman serta pelayanan yang memuaskan oleh pengelola maupun masyarakat khususnya di obyek Candi Tebing Gunung Kawi Tampaksiring.

Kondisi ekonomi wisatawan dengan penghasilan yang cukup memadai untuk memenuhi kebutuhan tersier termasuk kebutuhan untuk rekreasi/wisata, juga mempengaruhi kunjungan wisatawan ke obyek Candi Tebing Gunung Kawi. Demikian pula dengan gaya hidup wisatawan yang menyukai panorama alam indah yang masih alami serta kehidupan sosial budaya masyarakat lokal yang menarik, sesuai dengan kondisi alam dan budaya pada Candi Tebing Gunung Kawi. Selanjutnya faktor motivasi wisatawan berkunjung ke obyek Candi Tebing Gunung Kawiuntuk rekreasi menghindari rutinitas pekerjaan dan lingkungan kehidupan kota yang sudah tercemar serta hiruk-pikuk lalu-lintas yang krodit/macet, sangat sesuai dengan motivasi wisatawan untuk menikmati keindahan pemandangan alam yang masih lestari serta kehidupan budaya yang menarik dari masyarakat Kintamani dan Bali pada umumnya. Faktor sosial merupakan indikator yang paling kecil pengaruhnya terhadap karakteritik individu, karena wisatawan yang berkunjung ke obyek Candi Tebing Gunung Kawi bukan untuk menunjukkan status sosial mereka, tetapi lebih prioritas untuk menikmati keindahan alam dengan sungai dan persawahan yang masih terjaga kelestariannya serta kehidupan budaya yang unik.

\section{Image Wisatawan}

Image wisatawan yang terdiri dari faktor lingkungan yang nyaman, udara yang sejuk dan segar, kondisi menyenangkan, lingkungan yang bersih dan aman, juga merupakan faktor yang besar pengaruhnya terhadap pengambilan keputusan berkunjung ke obyek Candi Tebing Gunung Kawi. Lingkungan yang nyaman merupakan faktor yang paling besar mempengaruhi image wisatawan, karena obyek Candi Tebing Gunung Kawi memiliki pemandangan yang indah dengan view sungai dan persawahan serta kehidupan flora dan fauna yang masih terjaga kelestariaanya, serta kesenian dan budaya tradisional masyarakat setempat yang menarik dengan adanya obyek wisata Desa Kedisan yang merupakan Desa Tampaksiring. Obyek Candi Tebing Gunung Kawidengan udara yang sejuk dan segar juga berpengaruh besar terhadap image wisatawan yang berkunjung ke obyek wisata ini. Udara yang sejuk dan segar obyek Candi Tebing Gunung Kawi karena berlokasi pada lingkungan yang masih terjaga kelestariaannya. Kondisi ini tentu harus 
mendapat perhatiaan dari Pemerintah Kabupaten Gianyar agar tetap menjaga kelestarian lingkungan di obyek Candi Tebing Gunung Kawisehingga tetap segar dan sejuk.

Obyek Candi Tebing Gunung Kawidengan suasana menyenangkan berpengaruh besar terhadap image wisatawan yang berkunjung ke obyek wisata ini. Berwisata ke obyek Candi Tebing Gunung Kawi sangat menyenangkan, karena pemandangannya yang indah dengan view sungai dan sawah yang lingkungannya masih asri dengan atraksi wisata yang menarik. Lingkungan yang bersih dan aman merupakan dua faktor yang pengaruhnya relatif kecil terhadap image wisatawan yang berkunjung ke obyek Candi Tebing Gunung Kawi. Kebersihan lingkungan obyek Candi Tebing Gunung Kawi perlu mendapat perhatian dari pengelola obyek Candi Tebing Gunung Kawi terutama yang berada di obyek wisata Tampaksiring yaitu dengan menyediakan kotak-kotak tempat sampah yang lebih banyak lagi di tempat-tempat yang strategis yang ramai dikunjungi wisatawan.

Lingkungan yang aman dari obyek Candi Tebing Gunung Kawijuga perlu mendapat pengawasan yang maksimal dari pengelola obyek Candi Tebing Gunung Kawi, sehingga wisatawan yang berkunjung ke obyek ekowisata ini merasa aman, karena terlindungi oleh petugas keamanan desa adat/pecalang serta guide lokal yang lebih mengenal obyek Candi Tebing Gunung Kawi dan terhindar dari resiko kecelakaan karena lalu lintas yang masih kurang tertib. Wisatawan yang merasa aman berkunjung ke obyek Candi Tebing Gunung Kawi dan senantiasa dijaga kebersihan lingkungannya akan merupakan promosi word of mouth yang efektif untuk mendorong peningkatan kunjungan wisatawan ke obyek Candi Tebing Gunung Kawi.

\section{Pengambilan Keputusan Berkunjung}

Pengambilan keputusan berkunjung wisatawan ke obyek Candi Tebing Gunung Kawi dipengaruhi oleh faktor kesadaran adanya kebutuhan, mencari informasi, keputusan berkunjung dan evaluasi pasca kunjungan. Faktor yang paling besar berpengaruh terhadap pengambilan keputusan berkunjung adalah keputusan berkunjung yang didorong terutama oleh motivasi pribadi, yaitu adanya dorongan dari keluarga, teman, tetangga, kenalan dan promosi yang efektif serta adanya pengalaman berkunjung ke obyek ekowisata ini. Kesadaran adanya kebutuhan merupakan faktor kedua yang berpengaruh terhadap pengambilan keputusan berkunjung yang didorong terutama oleh adanya kebutuhan sosial, terutama harga diri, pengakuan dan status sosial serta Kondisi diri pribadi, yaitu menyangkut pekerjaan, kemampuan ekonomi dan gaya hidup. Evaluasi pasca kunjungan merupakan faktor ketiga yang berpengaruh terhadap pengambilan keputusan berkunjung, yang terdiri dari evaluasi terhadap atraksi wisatanya, harga, akomodasi, produk kenangan, kemudahan dijangkau, lingkungan yang bersih dan aman. 
Mencari informasi merupakan faktor yang paling lemah pengaruhnya terhadap pengambilan keputusan berkunjung yang terdiri dari publikasi, informasi wisatawan yang telah berkunjung ke obyek Candi Tebing Gunung Kawi serta jaringan sosial lainnya. Hasil ini mengindikasikan bahwa pemerintah dan maupun masyarakat di Tampaksiring agar lebih intensif mempublikasikan obyek Candi Tebing Gunung Kawi, khususnya melalui website sehingga dapat menjangkau jaringan internasional.

\section{Simpulan}

Variabel atribut obyek wisata, promosi, karakteristik individu, dan image berpengaruh terhadap keputusan berkunjung wisatwan ke Objek Wisata Candi Tebing Gunung Kawi Tampaksiring. Atribut obyek wisata berpengaruh positif signifikan terhadap image wisatawan. Promosi tidak berpengaruh signifikan terhadap image wisatawan. Karakteristik individu berpengaruh positif dan signifikan terhadap image wisatawan. Dan image wisatawan berpengaruh positif dan signifikan terhadap keputusan berkunjung wisatawan ke obyek wisata Candi Tebing Gunung Kawi Tampaksiring.

Dalam usaha untuk meningkatkan produk kenangan sebagai salah satu atribut obyek wisata, diperlukan upaya yang lebih maksimal dari pengelola obyek Candi Tebing Gunung Kawi dengan memotivasi para pedagang souvenir agar dapat memberikan pelayanan yang lebih memuaskan kepada para wisatawan.

\section{Daftar Pustaka}

Andreu, Luisa, J. Enrique Bigne and Chris Cooper. 2000. Projected and Perceived Image of Spain as Tourist Destination for British Travellers. Journal of Travel \& Tourism Marketing Vol. 9 No.4.

Ahmed, Z.U. 1996. The Need for The Identification of The Constituents of a Destination's Tourist Image: A Promotion Segmentation Perspective. Journal of Professional Services Marketing, Vol. 14

Tamba dan Setia Sapta. 2011. Sistem Pengelolaan Ekowisata Kintamani untuk Mendukung Cagar Budaya. Kementrian Pariwisata Republik Indonesia.

Baksir, Abdurrachman., Fredinan Yulianda. T.F. Djamar Lumbatu. M.F. Rahardjo. 2009. Model Pengelolaan Ekowisata Pulau-pulau Kecil Berkelanjutan di Kecamatan Morotai Selatan dan Morotai Selatan Barat Kabupaten Halmahera Utara, Propinsi Maluku Utara. Jurnal Ilmu Kelautan dan Perikanan Vol. 19 (1) p: 1-8

Bennet, P.D. 1995. Dictionary of Marketing Terms, American Marketing Association. Chicago: NTC Bussiness Books.

Chen, C-C.2004. Resident Perception of The Effect of Tourism: A Case Study of The Crystal Basin Recreation Area, California. e-Review of Tourism Research, Vol. 37 No. 3, pp. 256-66.

Engel, JF., Roger D. Blackwell and Paul W. Miniard. 1995. Perilaku Konsumen, Jilid 1 dan 2. Edisi keenam. Alih Bahasa Budijanto. Jakarta Barat: Binarupa Aksara.

Fandeli, C. 1995. Dasar-dasarManajemen Kepariwisataan Alam. Yogyakarta: Penerbit Liberty. 
Gartner, W.C. 1993. Image Foundation Process. Journal of Travel \& Tourism Marketing, 2(3), p191-215.

Gronroos, C. 1990. Service Management and Marketing: Managing The Moment of Truth in Service Competition. Lexingtoon Blokks. Maxwell MacMillan International Edition.

Hawkins, Del I., R.J. best and K.A. Coney. 1998. Consumer Behavior, Building Marketing Strategy, Seventh Edition. McGraw-Hill.

Kalebos, F. (2016). Faktor-faktor yang mempengaruhi kepuasan wisatawan yang berkunjung ke Daerah Wisata Kepulauan. Jurnal riset bisnis dan manajemen, 4(3), 489-502.

Kotler, P. 2003. Dasar-dasar Pemasaran. Edisi kesembilan. Jilid 1. Terjemahan Tim Markplus. Jakarta: PT Indeks Kelompok Gramedia.

Laws, E. 1995. Tourist Destination Management: Issues, Analysis and Policies. London: Routledge.

Lisma, N., Yonaldi, S., \& Zulbahri, L. (2017). Faktor-Faktor yang Mempengaruhi Kunjungan Wisatawan ke Objek Wisata Syariah di Sumatera Barat. Manajemen dan Kewirausahaan, $8(1), 38-52$.

Marpaung, H. 2002. Pengetahuan Pariwisata. Edisi Revisi. Bandung: Penerbit ALFABETA.

Moutindo, L. 1987. Consumer Behavior in Tourism. European Journal of Marketing, 21 (10), p 144

Simamora, B. 2002. Panduan Riset Perilaku Konsumen. Jakarta: Penerbit PT Gramedia Pustaka Utama.

Susilawati. 2008. Pengembangan Ekowisata Sebagai Salah Satu Upaya Pemberdayaan Sosial, Budaya Dan Ekonomi di Masyarakat. Jurnal Pendidikan Geografi UPI ISSN 1412-0313 Vol 8 No.1.

Sutisna. 2003. Perilaku Konsumen dan Komunikasi Pemasaran. Bandung: PT Remaja Rosdakarya Offset.

TIES (The International Ecotourism Society). 2006. Fact Sheet: Global Ecotourism. Updated Edition, September 2006. 